\title{
p53-Dependent Transcriptional Control of Cellular Prion by Presenilins
}

\author{
Bruno Vincent, ${ }^{1,2}$ Claire Sunyach, ${ }^{1,2}$ Hans-Dieter Orzechowski, ${ }^{3}$ Peter St George-Hyslop, ${ }^{4,5}$ and Frédéric Checler ${ }^{1,2}$ \\ ${ }^{1}$ Institut de Pharmacologie Moléculaire et Cellulaire and ${ }^{2}$ Institut de Neuro-Médecine Moléculaire, Unité Mixte de Recherche 6097 Centre National de la \\ Recherche Scientifique/Université de Nice-Sophia-Antipolis, Equipe labellisée Fondation pour la Recherche Médicale, 06560 Valbonne, France, ${ }^{3}$ Institute of \\ Clinical Pharmacology and Toxicology, Charité-Universitaetsmedizin Berlin, 10117 Berlin, Germany, ${ }^{4}$ Centre for Research in Neurodegenerative Diseases, \\ Department of Medicine, University of Toronto and University Health Network Toronto Western Hospital Research Institute, Toronto, Ontario M5S 3H2, \\ Canada, and ${ }^{5}$ Cambridge Institute of Medical Research, University of Cambridge, Cambridge CB2 OXY, United Kingdom
}

The presenilin-dependent $\gamma$-secretase processing of the $\beta$-amyloid precursor protein ( $\beta \mathrm{APP}$ ) conditions the length of the amyloid $\beta$ peptides $(\mathrm{A} \beta)$ that accumulate in the senile plaques of Alzheimer's disease-affected brains. This, together with an additional presenilinmediated $\varepsilon$-secretase cleavage, generates intracellular $\beta$ APP-derived fragments named amyloid intracellular domains (AICDs) that regulate the transcription of several genes. We establish that presenilins control the transcription of cellular prion protein $\left(\operatorname{PrP}^{c}\right)$ by a $\gamma$-secretase inhibitor-sensitive and AICD-mediated process. We demonstrate that AICD-dependent control of $\operatorname{PrP}^{\mathrm{c}}$ involves the tumor suppressor p53. Thus, p53-deficiency abolishes the AICD-mediated control of $\operatorname{PrP}^{c}$ transcription. Furthermore, we show that p53 directly binds to the $\operatorname{PrP}^{\mathrm{c}}$ promoter and increases its transactivation. Overall, our study unravels a transcriptional regulation of $\operatorname{Pr} \mathrm{P}^{\mathrm{c}}$ by the oncogene 53 that is directly driven by presenilin-dependent formation of AICD. Furthermore, it adds support to previous reports linking secretase activities involved in $\beta$ APP metabolism to the physiology of $\operatorname{PrP}^{c}$.

\section{Introduction}

Transmissible spongiform encephalopathies (TSE) result from the unconventional conversion of the normal cellular prion protein $\left(\operatorname{PrP}^{c}\right)$ into its pathogenic, protease-resistant scrapie isoform $\operatorname{PrP}^{\text {s.c. }}$ (Aguzzi and Polymenidou, 2004). The propagation mechanism apparently does not require any nucleic acid as was proposed in the "protein only" theory (Prusiner, 1998). Tremendous efforts have been devoted to understand the mechanisms by which $\operatorname{PrP}^{c}$ converts into $\operatorname{PrP}^{\text {s.c. }}$ Although the precise process remains to be established, it appears clearly that "prion infection" requires the crucial presence of endogenous $\operatorname{PrP}^{c}$, since $\operatorname{PrP}^{c}$ deficient mice are fully resistant to infection and toxicity after inoculation with pathogenic scrapie-enriched material (Büeler et al., 1993; Brandner et al., 1996). However, since prion diseases are extremely rare with no more than one case per million of individuals in human beings, it is important to understand the physiological role and regulation of $\operatorname{PrP}^{c}$.

$\operatorname{PrP}^{c}$ was reported to participate in lymphocyte activation (Cashman et al., 1990), cellular adhesion processes (Rieger et al., 1997; Gauczynski et al., 2001; Mangé et al., 2002), neurite growth

Received Feb. 16, 2009; revised March 30, 2009; accepted April 17, 2009.

This work was supported by the Fondation pour la Recherche Médicale and by the Conseil Général des AlpesMaritimes. We thank Drs. S. Pimplikar (Cleveland, OH), U. Müller (Heidelberg, Germany), M.F. Roussel (Memphis, TN), B. De Strooper (Leuven, Belgium), and P. Saftig (Göttingen, Germany) for kindly providing cell lines and brain samples. We sincerely thank T. C. Südhof (Dallas, TX), G. Thinakaran (Chicago, IL), J. C. Bourdon (Dundee, Scotland, UK), and L. Mercken (Vitry-sur-Seine, France) for their generous gift of cDNAs and antibodies.

Correspondence should be addressed to either Bruno Vincent or Frédéric Checler, Institut de Neuromédecine Moléculaire, UMR6097 CNRS/UNSA, 660 route des lucioles, 06560 Valbonne, France, E-mail: vincentb@ipmc.cnrs.fr or checler@ipmc.cnrs.fr.

D0I:10.1523/JNEUROSCI.0789-09.2009

Copyright $\odot 2009$ Society for Neuroscience $\quad$ 0270-6474/09/296752-09\$15.00/0
(Santuccione et al., 2005), synaptogenesis (Kanaani et al., 2005), cellular signaling (Mouillet-Richard et al., 2000), and cell viability (for review, see Linden et al., 2008). Concerning transcriptional regulation of $\operatorname{PrP}^{\mathrm{c}}$, it has been reported that $\operatorname{PrP}^{\mathrm{c}}$ mRNA levels could be increased either under stress conditions such as ischemia and hypoglycemia, or by some growth factors (Linden et al., 2008). However, little is known about the molecular pathways underlying these regulatory events. The functional characterization of the human prion promoter (Funke-Kaiser et al., 2001) identified two regulatory regions where sequence analysis revealed consensus sequences for $\mathrm{AP}-1, \mathrm{Sp} 1$, and $\mathrm{Sp} 2$ factors (Mahal et al., 2001; Bellingham et al., 2009). Our in silico analysis of the human PRioN protein (PRNP) gene promoter also revealed a motif partly matching the binding sequence targeted by the oncogene p53. We have examined the ability of p53 to modulate $\operatorname{PrP}^{c}$ promoter transactivation and mRNA expression and we show that $\mathrm{p} 53$ acts as a transcriptional activator of $\operatorname{PrP}^{\mathrm{c}}$ by binding directly to the suspected promoter sequence. Furthermore, we previously established that the $\beta$-amyloid precursor protein ( $\beta$ APP-intracellular domain amyloid intracellular domain (AICD) generated after presenilin-dependent $\gamma$-secretasemediated cleavage of $\beta$ APP behaves as a transcriptional activator of p53 (Alves da Costa et al., 2006). Here, we show that presenilins also control $\operatorname{PrP}^{c}$ transcription in a presenilin-dependent manner by increasing AICD-induced p53 expression. Our study is the first demonstration of the involvement of presenilins in the control of $\operatorname{PrP}^{\mathrm{c}}$ expression and reveals a new pathway linking $\gamma$-secretase and p53 to the direct control of $\operatorname{PrP}^{c}$ transcription. Since endogenous $\operatorname{PrP}^{c}$ is necessary to allow $\operatorname{PrP}^{\text {s.c. }}$ infectious process, presenilin-dependent control of $\operatorname{PrP}^{c}$ levels could be 
seen as a means to modulate not only the physiological function of $\operatorname{PrP}^{c}$ but also $\operatorname{PrP}^{\text {s.c. }}$ accumulation. This hypothesis is nicely supported by a recent study showing that a $\gamma$-secretase inhibitor significantly impairs the accumulation of pathogenic prions in vivo (Spilman et al., 2008), suggesting that such compounds could represent a new class of therapeutic agents against prion diseases.

\section{Materials and Methods}

Cell culture and transfections. Embryonic mouse fibroblasts [presenilindeficient $\left(\mathrm{PS}^{-1-}\right), \beta \mathrm{APP}-$ deficient $\left(\mathrm{APP}^{-1-}\right), \mathrm{APP}^{-1-} / \mathrm{APLP}^{-1-}$, $\mathrm{p} 19^{\mathrm{Arf}-1-}$, and $\mathrm{p} 19^{\mathrm{Arf}-1-} / \mathrm{p} 53^{-1-}$, as well as their respective wild-type controls], $\beta$ APP-over-expressing HEK293 cells and primary cultured neurons were obtained and maintained in culture as previously described (Vincent et al., 1996; Kamijo et al., 1997; Marambaud et al., 1997; Heber et al., 2000; Herreman et al., 2000; Pardossi-Piquard et al. 2005). Transient transfections in HEK293 cells were performed with Lipofectamine 2000 reagent (Invitrogen), whereas fibroblasts were transiently transfected by means of the mouse embryonic fibroblasts Nucleofector kit (Amaxa Biosystems) as described previously (Sunyach et al., 2007).

Immunoprecipitation, SDS-PAGE, and Western blotting. N1containing conditioned media were immunoprecipitated and submitted to $16.5 \%$ Tris-tricine gels as previously described (Vincent et al., 2000). $\beta$ APP, APLP1, APLP2, Fe65, Tip60, and p53 were separated on 8\% Trisglycine gels, whereas $\operatorname{PrP}^{c}$, tubulin, PS1, and PS2 were analyzed on $12 \%$ Tris-glycine gels. C50 and C59 fragments were separated on 16.5\% Tristricine gels. Proteins were then transferred onto Hybond-C nitrocellulose membranes and incubated with the following antibodies: monoclonal SAF32 (N1 and PrP ; SPIBio), monoclonal anti- $\beta$-tubulin or anti- $\beta$ actin (Sigma), polyclonal anti-NTF-PS1 or anti-Loop-PS2 (Dr. Gopal Thinakaran, University of Chicago, Chicago, IL), polyclonal anti-Fe65 and monoclonal anti-myc (for myc-tagged C50 and C59; Dr. L. Mercken, Vitry-sur-Seine, France), monoclonal anti-HA (HA-tagged Tip60; Covance), polyclonal anti-APLP1 or APLP2 (EMD Biosciences), monoclonal 22C11 ( $\beta$ APP; Roche Applied Science), or polyclonal anti-p53 (Dr. Jean-Christophe Bourdon, Dundee, Scotland, UK). Blots were revealed by incubations with goat anti-rabbit or goat anti-mouse secondary antibodies coupled to peroxidase (Beckman Coulter) and chemiluminescence recording using a Luminescence Image Analyzer LAS-3000 (Raytest). Quantification of data was performed with the Aida Image Analyzer software (Raytest).

Chronic $\gamma$-secretase inhibitor treatments. Chronic treatment of 4-d-old primary cultured neurons with the $\gamma$-secretase inhibitor DAPT $(\mathrm{N}-[-(3$, 5-difluorophenacetyl)-L-alanyl]-S-phenylglycine t-butylester; $10 \mu \mathrm{M})$ was performed by addition of the inhibitor at 0 and $9 \mathrm{~h}$ for a total incubation of $24 \mathrm{~h}$ then $\operatorname{PrP}^{\mathrm{c}}$ immunoreactivity was monitored by Western blot as described above.

Semiquantitative and real-time PCR analyses. Total RNA was extracted and purified from mouse embryonic fibroblasts or HEK293 cells with the NucleoSpin RNA II kit (Machery-Nagel). Two micrograms of total RNA were reverse-transcribed using oligo (dT) priming and avian myeloblastosis virus reverse transcriptase (Promega). For semiquantitative PCR, reactions were performed at $94^{\circ} \mathrm{C}$ for $30 \mathrm{~s}$, then $55^{\circ} \mathrm{C}$ for $1 \mathrm{~min}$, and finally $68^{\circ} \mathrm{C}$ for 2 min using 40 cycles, followed by a final extension of 7 $\min$ at $68^{\circ} \mathrm{C}$. PCR products were analyzed on a $1 \%$ agarose gel stained with ethidium bromide. Real-time PCR were performed in an ABI PRISM 5700 sequence detector system (Applied Biosystems) using the SYBR Green detection protocol as outlined by the manufacturer. Specific primers for semiquantitative or real-time PCR were designed using the Primer Express software (Applied Biosystems) and were as follows: mouse $\operatorname{PrP}^{c}$ : forward, 5'-CTG CTG GCC CTC TTT GTG AC-3' and reverse $5^{\prime}$-CTT TTT GCA GAG GCC GAC AT-3'. Human PrP ${ }^{c}$ : forward, 5'-AAT CAA GCA GCA CAC GGT CA-3' and reverse 5' -TCG GTG AAG TTC TCC CCC TT-3'.

Expression levels of human p53 and $\operatorname{PrP}^{\mathrm{c}}$ genes and mouse $\operatorname{PrP}^{\mathrm{c}}$ gene were normalized by monitoring RNA levels of human GAPDH and mouse $\gamma$-actin genes using the following primers: forward, $5^{\prime}$-TGG GCT ACA CTG AGC ACC AG-3' and reverse 5' -CAG CGT CAA AGG TGG AGG AG-3' for human GAPDH; and forward 5'-CAC CAT CGG TTG
TTA GTT GCC-3' and reverse 5' -CAG GTG TCG ATG CAA ACG TT-3' for mouse $\gamma$-actin.

Measurements of $\operatorname{Pr} P^{c}$ promoter transactivation. The 1543 bp of the $5^{\prime}$ untranslated and promoter region of the human $\operatorname{PrP}^{c}$ gene was subcloned into the luciferase reporter vector pGL3basic and used to measure $\operatorname{PrP}^{\mathrm{c}}$ promoter transactivation as has been extensively described (FunkeKaiser et al., 2001). Cells grown in 12-well plates were cotransfected with $\operatorname{PrP}^{\mathrm{c}}$ promoter-luciferase, $\beta$-galactosidase (to normalize transfection efficiencies), and the indicated cDNAs with Lipofectamine (HEK293 cells) or with the Amaxa Nucleofector kit (mouse embryonic fibroblasts). Thirty-six hours after transfection, luciferase and $\beta$-galactosidase activities were measured with appropriate enzyme assay systems (Promega).

Site-directed mutagenesis of $\operatorname{PrP}^{c}$ promoter. Mutation of the p53 putative binding site located on the human $\operatorname{PrP}^{\mathrm{c}}$ promoter-luciferase reporter construct (Mahal et al., 2001) was introduced using the Quick change site-directed mutagenesis kit (Stratagene) following manufacturer's specifications. The two following sets of primers were purchased from Eurogentec: forward, 5'-CCTATTTTCCCCAGGGAGCACCTGGTTTACGCCC-3'; reverse, 5'-GGGCGTAAACCA-GGTGCTCCCTGGGGAAAATAGG- $3^{\prime}$. The resulting construct (CATG replaced by AGCA) was verified by sequencing.

Chromatin immunoprecipitation assay. Chromatin immunoprecipitation assay (ChIP) was performed according to the instructions of the Chip-IT kit (Active Motif). Briefly, to prepare chromatin, HEK293 cells were seeded in three $150 \mathrm{~mm}$ dishes and allowed to reach $70-80 \%$ confluency. Cells were fixed, recovered in PBS, cross linked, and processed for chromatin preparation. DNA obtained was digested with the shearing enzyme provided in the kit as recommended by the supplier, yielding chromatin fragments of $200-500 \mathrm{bp}$ in size. Each immunoprecipitation was performed on $50 \mu \mathrm{g}$ of chromatin in the ChIP immunoprecipitation buffer supplied, with $5 \mu$ g of anti-p53 primary antibody (Active Motif) or irrelevant antibody (IgG and RNApol IgG) as negative controls. Immune complexes were collected with $40 \mu \mathrm{l}$ of a solution of protein G-Sepharose. After elution, cross links were reversed and RNA digested using RNase (100 $\mu \mathrm{g} / \mathrm{ml})$. To digest proteins, SDS (1\%), and proteinase $\mathrm{K}(100 \mu \mathrm{g} / \mathrm{ml})$ were added, and the samples were incubated overnight at $37^{\circ} \mathrm{C}$. The beads were washed as recommended and DNA was purified on columns provided. PCR amplification was performed using primers specific for the $-326 /-150$ bp region of the $\operatorname{PrP}^{\mathrm{c}}$ promoter (forward, $5^{\prime}$ CAGGAGCCACACAGTTGAAACAGA-3'; reverse, 5-AGGGTGATTTACGTAAAATAGCAAA- $3^{\prime}$ ).

Transgenic mouse brain tissue preparation. Pieces of brains from $\mathrm{APP}^{-1-}$ and $\mathrm{APP}^{-1-} / \mathrm{APLP}^{-1-}$ mice (Heber et al., 2000), and Fe65 transgenic and Fe65/AICD transgenic mice (Ryan and Pimplikar, 2005), together with their respective wild-type controls, were homogenized in lysis buffer (10 mM Tris/HCl, pH 7.5, containing $150 \mathrm{~mm} \mathrm{NaCl,} \mathrm{0.5 \%}$ Triton X-100, 0.5\% deoxycholate, 5 mм EDTA). Protein expressions were analyzed by Western blot as described above.

Immunofluorescence analysis. Wild-type, $\mathrm{PS}^{-1-}$, or $\mathrm{APP}^{-1-}$, $\mathrm{APLP}^{-1-}$ fibroblasts were grown on glass coverslips in $35 \mathrm{~mm}$ dishes. At $50 \%$ of confluence, cells were fixed with $1.5 \%$ paraformaldehyde for $20 \mathrm{~min}$ at room temperature and washed three times with PBS. Permeabilization was performed by the addition of $0.1 \%$ Triton X-100 for 5 min followed by three PBS washes (nonpermeabilized cells were maintained in PBS during this time). After incubation for $1 \mathrm{~h}$ with $1 \%$ nonfat milk in PBS (to limit nonspecific fixation of antibodies), cells were incubated overnight at $4^{\circ} \mathrm{C}$ with the indicated primary antibodies in $1 \%$ nonfat milk/PBS). After three washes with PBS, cells were incubated for $1 \mathrm{~h}$ with adequate secondary antibodies conjugated to Alexa Fluor-594 and Alexa Fluor-488 respectively (Interchim). Coverslips were washed, incubated with DAPI to counterstain the nuclei and mounted in Vectashield-mounting medium (Vector Laboratories). Staining was visualized as previously described (Sunyach et al., 2007).

Statistical analysis. Statistical analyses were performed with the PRISM software (GraphPad) by using the unpaired $t$ test for pairwise comparisons. 

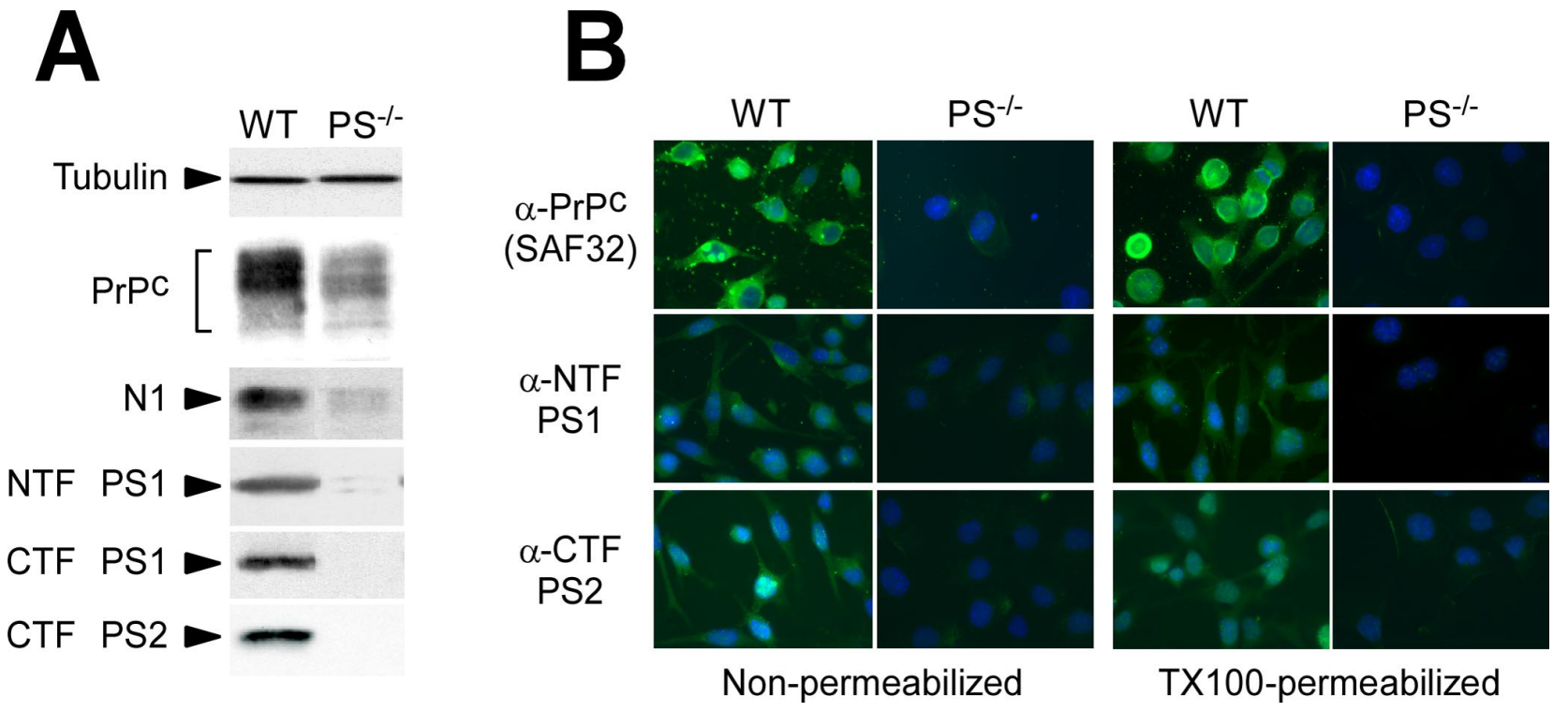

Figure 1. Presenilins deficiency reduces $\operatorname{PrP}^{c}$ immunoreactivity. $A$, Wild-type (WT) or PS ${ }^{-1-}$ mouse fibroblasts were incubated for 8 h in serum-free medium; then the secreted $P_{r}{ }^{c} \mathrm{~N}$-terminal metabolite (N1) was immunoprecipitated and analyzed by $16.5 \%$ Tris/Tricine electrophoresis, and Western blot as described in Materials and Methods. PrPc, tubulin, and presenilin 1 and 2 immunoreactivities were monitored in cell homogenates as described in Materials and Methods. $\boldsymbol{B}$, WT and PS ${ }^{-1-}$ cells were fixed and labeled under nonpermeabilized or Triton X-100permeabilized conditions with antibodies directed toward PrP ${ }^{\mathrm{C}}$ (SAF32), N-terminal (NTF), and C-terminal (CTF) parts of presenilins ( $\alpha$-NTF PS1 and $\alpha$-CTF PS2, respectively) as described in Materials and Methods. Cells were then counterstained with DAPI to visualize nuclei and analyzed on an Axioplan microscope.

\section{Results}

Presenilins modulate cellular prion protein at a transcriptional level

We examined the influence of presenilins on the expression of $\operatorname{PrP}^{c}$. Figure $1 A$ shows that $\operatorname{PrP}^{\mathrm{c}}$ immunoreactivity was drastically decreased $(50 \pm 3.7 \%$ inhibition compared with wild-type cells, $n=$ $20, p<0.0001)$ in homogenates prepared from presenilins 1- and 2-deficient $\left(\mathrm{PS}^{-1-}\right)$ mouse fibroblasts. As expected, the secretion of the N-terminal metabolite of $\operatorname{PrP}^{\mathrm{c}}$ referred to as N1 (Chen et al., 1995; Vincent et al., 2000, 2001) was concomitantly reduced by PS deficiency (Fig. 1A). In situ staining of $\operatorname{PrP}^{\mathrm{c}}$ on nonpermeabilized intact cells revealed a drastic decrease in cell surface-associated immunofluorescence in PS-deficient fibroblasts (Fig. $1 B$, left panels). $\mathrm{PrP}^{\mathrm{c}}$ labeling on Triton X-100 permeabilized cells revealed a similar decrease of $\operatorname{Pr}^{\mathrm{c}}$ expression triggered by PS depletion (Fig. $1 B$, right panels), indicating that the reduction of membraneassociated $\operatorname{PrP}^{c}$ expression was not caused by an intracellular accumulation of the protein that would have been triggered by a defect in PS-dependent trafficking of $\operatorname{PrP}^{c}$ to the plasma membrane.

We assessed whether the observed reduction in $\operatorname{PrP}^{c}$ immunoreactivity resulted from a decrease in its mRNA transcription. We took advantage of the design of a $\operatorname{PrP}^{\mathrm{c}}$ promoter construct that harbors $1543 \mathrm{bp}$ of the $5^{\prime}$-untranslated promoter region of the $\operatorname{PrP}^{\mathrm{c}}$ human gene in-frame with a luciferase reporter gene (Funke-Kaiser et al., 2001) to establish that $\operatorname{PrP}^{c}$ promoter transactivation was drastically reduced in PS-deficient fibroblasts
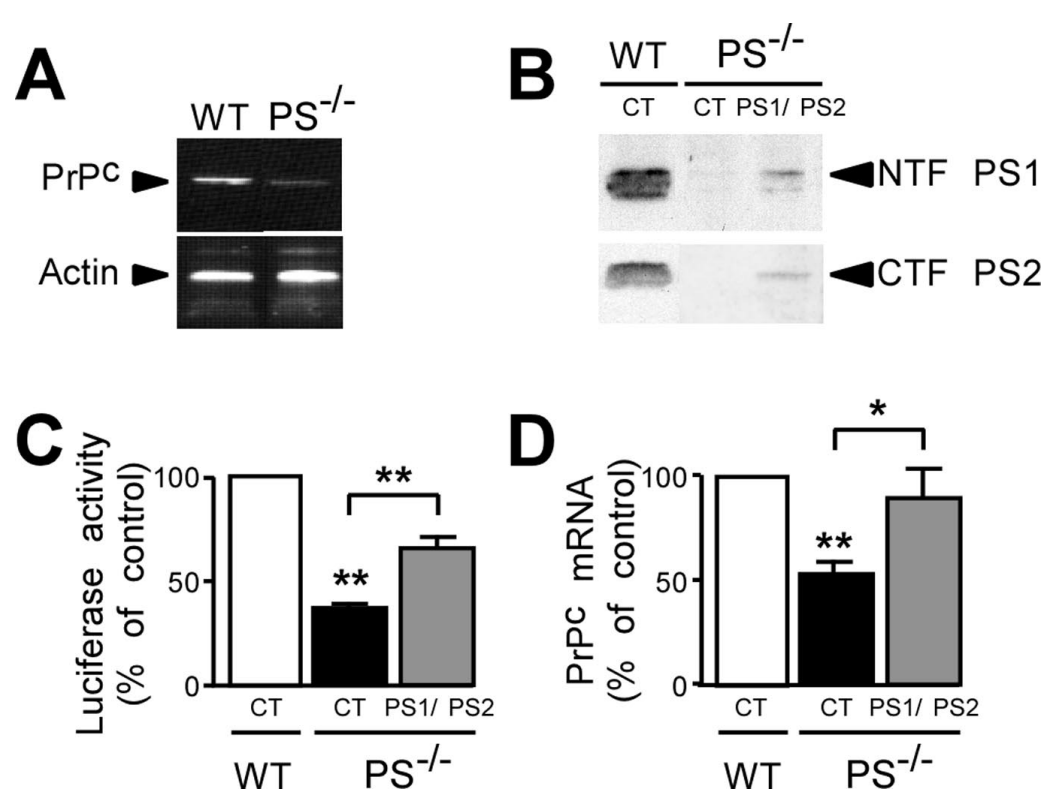

Figure 2. Presenilins regulate $\operatorname{PrP}^{c}$ expression at a transcriptional level. $A$, Analysis of $\operatorname{PrP}^{c}$ and actin mRNA levels by semiquantitative $P C R$ in wild-type (WT) and PS ${ }^{-1-}$ fibroblasts. $B-D, P S^{-1-}$ fibroblasts were transiently transfected with either empty pcDNA3 vector (CT) or with PS1 and PS2 CDNA (PS1/PS2) as described in Materials and Methods. Thirty-six hours after transfection, protein expression $(\boldsymbol{B}), \operatorname{PrP}^{c}$ promoter transactivation $(\boldsymbol{C})$, and mRNA levels $(\boldsymbol{D})$ were monitored. Bars in $\boldsymbol{C}$ and $\boldsymbol{D}$ express percentage of mock-transfected WT cells and represent the means \pm SEM of 10 or 6 independent experiments, respectively. ${ }^{*} p<0.05 ;{ }^{* *} p<0.0001$.

(63 $\pm 2.5 \%$ of reduction compared with wild-type cells, $n=15$, $p<0.0001$ ) (Fig. 2C). This was accompanied by a lowering of $\mathrm{PrP}^{\mathrm{c}}$ mRNA levels measured by both semiquantitative RT-PCR (Fig. $2 A$ ) and real-time PCR analyses ( $46.6 \pm 8.4 \%$ of reduction, $n=9, p<0.0001$ ) (Fig. 2D) in PS-deficient fibroblasts. Importantly, we were able to substantially rescue $\operatorname{PrP}^{\mathrm{c}}$ promoter transactivation (1.88 \pm 0.13 -fold increase, $p<0.0001)$ (Fig. $2 C)$ and mRNA levels (1.69 \pm 0.14 -fold increase, $p<0.05$ ) (Fig. $2 D$ ) after transient overexpression of both PS1 and PS2 in PS-deficient cells 

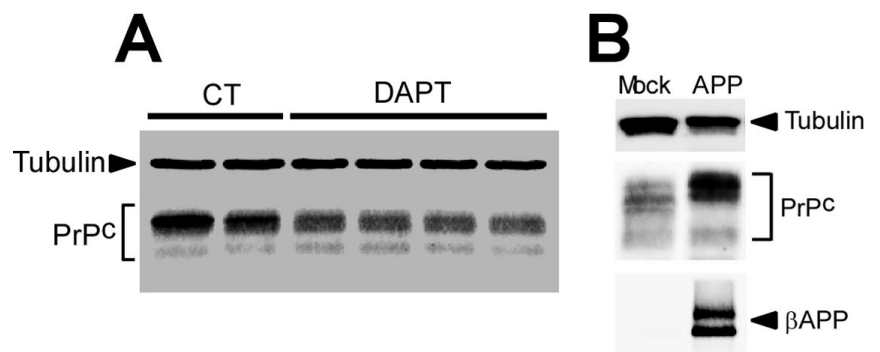

D

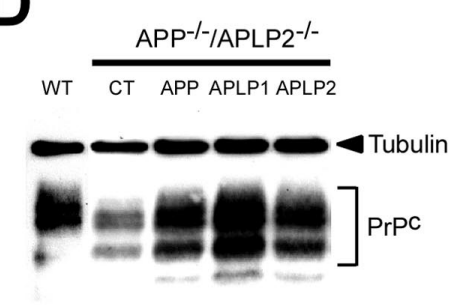

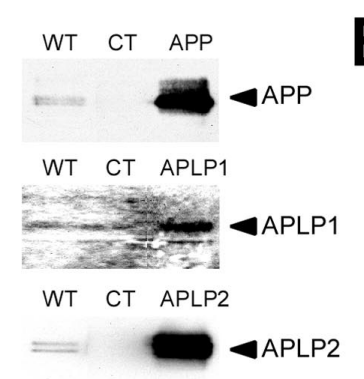
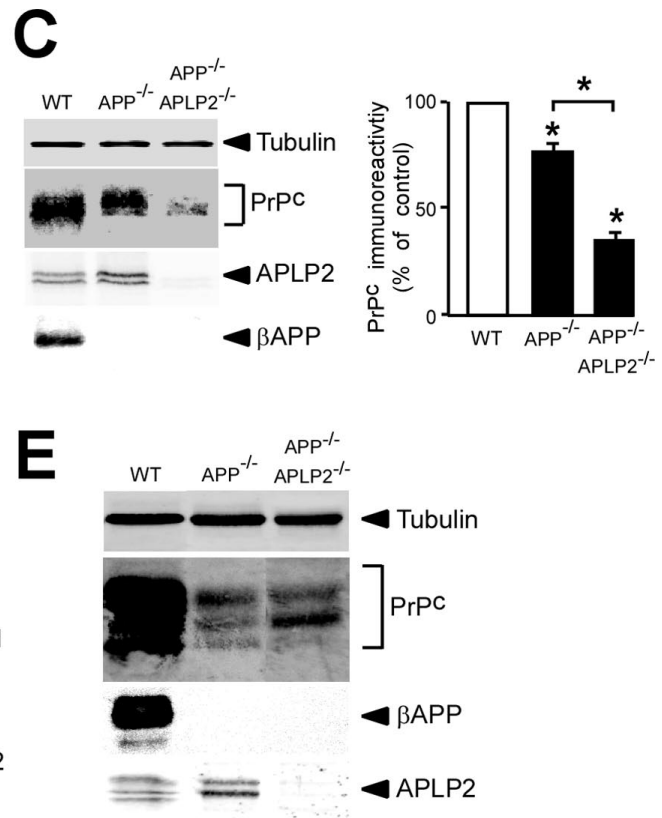

Figure 3. PrP cexpression is reduced by a $\gamma$-secretase inhibitor and is modulated by $\beta A P P$ and APLP2 in cells and in mice brain. A, Primary cultured neurons were chronically treated with the $\gamma$-secretase inhibitor DAPT $(10 \mu \mathrm{M})$ for a total period of $24 \mathrm{~h}$; then PrP ${ }^{c}$ and tubulin immunoreactivities were analyzed by Western blot as described in Materials and Methods. $\boldsymbol{B}$, PrP ${ }^{c}$ expression in stably transfected mock (mock)- and $\beta$ APP (APP)-expressing HEK293 cells (left). C, PrP', tubulin, $\beta$ APP, and APLP2 immunoreactivities in homogenates of wild-type (WT), $\beta$ APP-deficient $\left(\right.$ APP $^{-1-}$ ), and APP ${ }^{-1-} /$ APLP2 $^{-1-}$ fibroblasts (left) were monitored as described in Materials and Methods. Bars corresponding to densitometric analyses express percentage of control WT cells and represent the means \pm SEM of 20 independent experiments. ${ }^{*} p<0.0001$. D, Empty pcDNA3 (CT), $\beta$ APP (APP), APLP1, or APLP2 CDNAs were transiently transfected in APP $^{-/-} /$APLP2 $^{-/-}$ double knock-out fibroblasts. Thirty-six hours after transfection, PrP ' and tubulin immunoreactivities (left) or transgene expressions (right) were monitored as described in Materials and Methods. E, PrP' , tubulin, $\beta$ APP, and APLP2 immunoreactivities were monitored in whole homogenates prepared from WT, APP ${ }^{-1-}$, and APP ${ }^{-1-} /$ APLP2 $^{-1-}$ mice brains as described in Materials and Methods.

(Fig. 2 B). Overall, the above data demonstrate that the PSs control $\operatorname{PrP}^{\mathrm{c}}$ expression at the transcriptional level.

\section{$\beta A P P$ and APLPs are involved in the regulation of $\operatorname{PrP}^{\mathrm{c}}$ transcription}

PSs are pleiotropic proteins (Checler, 1999) that are thought to harbor an aspartyl protease activity referred to as $\gamma$-secretase (Wolfe et al., 1999). To assess whether the PS-dependent control of $\operatorname{PrP}^{\mathrm{c}}$ expression could be linked to $\gamma$-secretase activity, primary cultured neurons were exposed to DAPT, a specific PSdirected inhibitor (Dovey et al., 2001). Figure 3A clearly shows that chronic treatment of neurons with DAPT significantly reduced $\operatorname{PrP}^{\mathrm{c}}$ expression ( $37 \pm 4 \%$ inhibition, $n=3, p<0.0001$ ). The $\beta$ APP is historically the first protein described as a substrate of the PS-dependent $\gamma$-secretase activity (De Strooper et al., 1998). Furthermore, PS-dependent cleavage of $\beta A P P$ yields a C-terminal metabolite called AICD that has been suggested to behave as a transcription factor (Müller et al., 2008). We therefore examined whether $\beta$ APP could be involved in the control of $\operatorname{PrP}^{\mathrm{c}}$ expression and promoter transactivation. We first showed that $\beta$ APP overexpression triggers a significant increase of $\operatorname{PrP}^{c}$ immunoreactivity $(1.6 \pm 0.07$-fold increase, $n=8, p<0.0001)$ (Fig. 3B) in human stably transfected HEK293. To rule out any artifactual effect resulting from overexpression procedure and to confirm that endogenous $\beta$ APP indeed controls $\operatorname{PrP}^{c}$ expression, we monitored $\mathrm{PrP}^{\mathrm{c}}$ immunoreactivities in $\beta$ APP-deficient fibroblasts, and we observed a reduction of $\operatorname{PrP}^{\mathrm{c}}$ expression in absence of $\beta$ APP (19.3 $\pm 3.6 \%$ inhibition, $p<0.0001$ ) (Fig. $3 C$ ), a phenotype reminiscent of that observed in presenilin-deficient cells (Fig. 1A). Interestingly, the lowering of $\operatorname{PrP}^{c}$ expression was further amplified in $\beta \mathrm{APP}^{-1-} / \mathrm{APLP}^{-/-}$fibroblasts $(63 \pm 6 \%$ inhibition, $p<0.0001$ ) (Fig. $3 C$ ) that are lacking APLP2, a member of the $\beta A P P$ family that also undergoes PS-dependent $\gamma$-secretase-like cleavages (Scheinfeld et al., 2002). Interestingly, we show that $\operatorname{PrP}^{\mathrm{c}}$ immunoreactivity was fully restored by transient transfections of $\beta \mathrm{APP}$ or APLP2 $\mathrm{cDNAs}$ in $\beta \mathrm{APP}^{-1-}$ / APLP2 ${ }^{-1-}$ cells (Fig. $3 D$ ). It should be noted that APLP1, another member of the $\beta$ APP family that is expressed in the brain but absent in fibroblasts, mimics the potential of rescue harbored by $\beta A P P$ and APLP2 (Fig. 3D). The above findings were further supported by in vivo data showing a dramatic reduction of $\mathrm{PrP}^{\mathrm{c}}$ expression in both $\beta$ APP- and $\beta A P P / A P L P 2-d e f i c i e n t ~ m o u s e$ brains (Fig. 3E). Finally, immunofluorescence staining of $\operatorname{PrP}^{\mathrm{c}}$ at the cell surface of permeabilized and nonpermeabilized $\beta \mathrm{APP}^{-/-}$, APLP2 ${ }^{-1-}$ cells indicated that the combined absence of $\beta$ APP and APLP2 drastically impaired $\operatorname{PrP}^{\mathrm{c}}$ expression at the plasma membrane (Fig. 4A), as was observed in PS-deficient cells.

Four lines of data indicate that $\beta$ APP and APLP 2 control PrP ${ }^{c}$ expression at a transcriptional level. First, the transactivation of the human $\operatorname{PrP}^{c}$ promoter was significantly impaired by $\beta A P P$ and $\beta$ APP/APLP 2 depletion ( $63 \pm 5 \%$ reduction, $p<0.0001$ and $81 \pm 3 \%$ decrease, $p<0.0001$, respectively) (Fig. $4 B$ ). Second, $\beta A P P$ and $\beta A P P / A P L P 2$ deficiency lowered $\mathrm{PrP}^{\mathrm{c}}$ mRNA levels as shown by semiquantitative (Fig. $4 C$ ) and quantitative real-time PCR $(70 \pm 14 \%$ decrease, $p<0.01$ and $69 \pm 10 \%$ inhibition, $p<$ 0.003 , respectively) (Fig. $4 D$ ). Third, $\beta$ APP partially restored both $\operatorname{PrP}^{\mathrm{c}}$ promoter transactivation $(2.07 \pm 0.05$-fold increase, $p<0.0001$ ) and $\operatorname{PrP}^{c}$ mRNA levels (3.02 \pm 0.37 -fold increase, $p<0.03$ ) (Fig. $4 E$ ). Fourth, both luciferase activity $(2.75 \pm 0.14-$ fold increase, $n=6, p<0.0001)$ and $\mathrm{PrP}^{\mathrm{c}}$ mRNA levels $(1.93 \pm$ 0.11 -fold increase, $n=10, p<0.0001$ ) were significantly augmented after $\beta$ APP overexpression in HEK293 cells, ruling out a possible cell specific $\beta$ APP-mediated control of $\operatorname{PrP}^{c}$ transcription (data not shown). 
The $\boldsymbol{\gamma}$-secretase-derived $\beta$ APP metabolite AICD controls PrP $^{c}$ expression and promoter transactivation

The $\beta$ APP-related effects on $\operatorname{PrP}^{c}$ expression and transcription were fully reminiscent of those associated with PSs. Since the latter appeared dependent on $\gamma$-secretase activity, we reasoned that the production of a $\beta A P P$ metabolite generated by PS-dependent $\gamma$-secretase activity could account for the observed modulation of $\operatorname{PrP}^{\mathrm{c}}$ mRNA levels and protein expression. Interestingly, AICD59 (C59) and AICD50 (C50) derive from the $\gamma$ and $\varepsilon$-secretase attacks of $\beta \mathrm{APP}$, respectively, and have been suggested to modulate a series of genes at a transcriptional level (Müller et al., 2008). Therefore, we examined the possibility that AICD could modulate the transcription of $\operatorname{PrP}^{\mathrm{c}}$. The adaptor protein Fe65 and the histone acetyltransferase Tip60 have been reported to enhance AICD immunoreactivity and to promote AICD translocation to the nucleus (Cao and Südhof, 2001). Therefore, we transiently transfected C50 or C59 together with Fe65 and Tip60 in $\beta \mathrm{APP}^{-/-} / \mathrm{APLP}^{-/-}$fibroblasts (Fig. 5A). Clearly, both C50 and C59 overexpression significantly enhanced $\mathrm{PrP}^{\mathrm{c}}$ immunoreactivity (1.14 \pm 0.05 -fold increase, $p<0.005$ and $1.55 \pm 0.16$-fold increase, $p<0.005$, respectively) (Fig. $5 A$ ), $\mathrm{PrP}^{\mathrm{c}}$ promoter transactivation (1.13 \pm 0.04 fold increase, $p<0.002$ and $1.64 \pm 0.12$-fold increase, $p<0.0001$, respectively) (Fig. $5 B$ ), and $\operatorname{PrP}^{\mathrm{c}} \mathrm{mRNA}$ levels $(2.47 \pm 0.12$-fold increase, $p<0.05$ and $1.73 \pm 0.04$-fold increase, $p<0.05$, respectively) (Fig. $5 C$ ). Here again, both $\mathrm{C} 50$ and $\mathrm{C} 59$ heighten $\mathrm{PrP}^{\mathrm{c}}$ mRNA levels $(2.41 \pm 0.26$-fold increase, $p<$ 0.01 and $1.68 \pm 0.19$-fold increase, $p<0.03$, respectively) in HEK293 cells (Fig. 5D). Finally, we took advantage of transgenic mice overexpressing both C59 and Fe65 (Ryan and Pimplikar, 2005) to determine whether the AICD-mediated control of $\operatorname{PrP}^{\mathrm{c}}$ expression described here also takes place in vivo in mouse brain. Indeed, C59/Fe65 transgenic mice show enhanced cerebral expression of $\operatorname{PrP}^{\mathrm{c}}$ compared with Fe65 single transgenic animals (Fig. 5E). Since PS-dependent $\gamma$-secretase activity is able to cleave other substrates than $\beta$ APP, thereby generating other ICDs, we examined the effect of notch ICD (NICD), m $\Delta$ ENotch (which engenders NICD after $\gamma$-secretase cleavage), or the $\gamma$-secretase-derived C-terminal products of E- and $\mathrm{N}$-cadherins (E-Cad/CTF2 and N-Cad/CTF2, respectively), and established that none of these fragments were able to modulate $\operatorname{PrP}^{\mathrm{c}}$ levels (data not shown).

\section{AICD-mediated regulation of $\operatorname{PrP}^{c}$ is p53-dependent and} occurs through direct binding of $\mathrm{p} 53$ to $\mathrm{PrP}^{\mathrm{c}}$ promoter The question arises by which mechanisms AICD could control $\operatorname{PrP}^{\mathrm{c}}$ promoter transactivation, and thereby, mRNA and protein levels. We have previously demonstrated that AICDs can positively control p53 at the transcriptional level (Alves da Costa et al., 2006). In silico examination of the $\operatorname{PrP}^{\mathrm{c}}$ promoter revealed a putative although incomplete p53-binding site (el-Deiry et al., 1992) (Fig. 6B). It was therefore tempting to speculate on the possibility that p53 could account for the AICD-mediated regulation of $\operatorname{PrP}^{c}$ transcription. Six lines of independent data confirm that this was indeed the case. First, $\mathrm{PrPc}$ mRNA levels were reduced by p53 depletion (Fig. 6A). Second, C50- and C59mediated effects on $\operatorname{PrP}^{\mathrm{c}}$ mRNA levels were fully p53-dependent because the C50/59-induced increase in $\operatorname{PrP}^{c}$ mRNA was prevented by $\mathrm{p} 53$ depletion (Fig. $6 A$ ). Third, $\operatorname{PrP}^{\mathrm{c}}$ expression (de- 

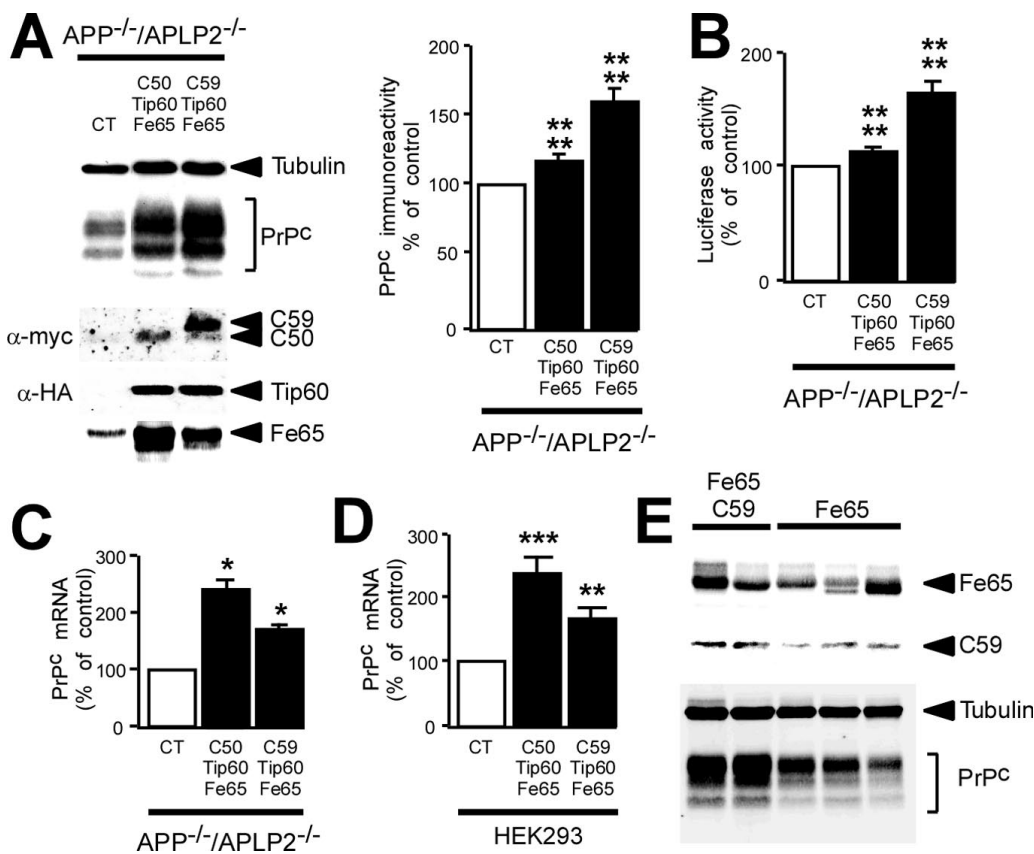

Figure 5. Presenilin-dependent control of $\operatorname{PrP}^{c}$ transcription is mediated by $\beta A P P$ intracellular domains. $A-C, A^{-1-}$ APLP2 ${ }^{-1-}$ fibroblasts were transiently transfected with empty pcDNA3 vector (CT) or C50/C59 CDNA together with Fe65 and Tip60-encoding plasmids as described in Materials and Methods. Thirty-six hours after transfection, $\operatorname{PrP}{ }^{C}$ expression $(\boldsymbol{A})$, promoter transactivation $(\boldsymbol{B})$ and mRNA levels $(\boldsymbol{C})$ were monitored as described in Materials and Methods. Bars express percentage of corresponding control values obtained with pcDNA3-transfected cells and represent the means \pm SEM of $12(\boldsymbol{A}), 3(\boldsymbol{B})$, or $4(\boldsymbol{C})$ independent determinations. ${ }^{*} p<0.05 ;{ }^{* * *} p<0.0003$. D, HEK293 cells were transiently transfected with empty pcDNA3 vector (CT) or either $\mathrm{C} 50$ or $\mathrm{C59}$ in combination with Fe65 and Tip60 CDNA in as described in Materials and Methods. Thirty-six hours after transfection, mRNA levels were monitored by real time PCR. Bars express percentage of control (pcDNA3-transfected cells) and represent the means \pm SEM of 3 independent experiments performed in triplicates. ${ }^{* *} p<0.03 ;{ }^{* * *} p<0.01 . \boldsymbol{E}$, Expressions of PrP $c$, 559 , Fe65, and tubulin were analyzed by Western blot, as described in Materials and Methods, in singly (Fe65) or doubly (Fe65/C59) transgenic mice brain homogenates.

crease of $34 \pm 8 \%, n=5, p<0.01$ ) (Fig. $6 C$ ), promoter transactivation (decrease of $49 \pm 5 \%, p<0.001$ ) (Fig. $6 D$ ), and mRNA levels (decrease of $55 \pm 15 \%, p<0.01$ ) (Fig. $6 E$ ) were reduced by p53 depletion. Fourth, p53 cDNA transfection in p53-deficient cells rescued $\operatorname{PrP}^{\mathrm{c}}$ promoter activation $(2.44 \pm 0.07$-fold increase, $p<0.0001$ ) (Fig. 6D) and mRNA levels (2.6 \pm 0.13 -fold increase, $p<0.001$ ) (Fig. $6 E$ ). Fifth, ChIP, using a set of primers framing the putative p53 binding site described above, showed that $\mathrm{p} 53$ physically bound to the human $\operatorname{PrP}^{\mathrm{c}}$ promoter (Fig. $6 \mathrm{~F}$, lane 5). Sixth, mutation of the putative p53 binding site located on the $\mathrm{PrP}^{\mathrm{c}}$ promoter reporter construct not only resulted in a significant decrease of baseline luciferase activity in p19 Arf -Icells expressing endogenous p53 levels (Fig. 6G, compare WT and Mut), but also abolished the ability of overexpressed p53 to trigger $\mathrm{PrP}^{\mathrm{c}}$ promoter transactivation (Fig. 6G, compare WT/p53 and Mut/p53). This set of data brings the demonstration that p53 could act as a direct activator of $\mathrm{PrP}^{\mathrm{c}}$ promoter transactivation and strongly argues in favor of a p53-mediated AICD-dependent regulation of $\operatorname{PrP}^{\mathrm{c}}$ transcription.

\section{Discussion}

Although the role of the $\operatorname{PrP}^{c}$ in transmissible spongiform encephalopathies has been clearly established (Aguzzi and Polymenidou, 2004), its physiological function as well as the regulation of its expression are yet poorly understood. The demonstration that $\operatorname{PrP}^{\mathrm{c}}$-deficient mice are viable with no obvious deleterious phenotype (Büeler et al., 1992) would suggest either that endogenous $\operatorname{PrP}^{\mathrm{c}}$ does not fulfill any vital functions, or that such functions could be complemented by yet unknown proteins/mechanisms. Nevertheless, several studies indicated that $\operatorname{PrP}^{\mathrm{c}}$ could contribute to several distinct processes, including lymphocyte activation, synaptic transmission, cell adhesion, signaling, and apoptosis (for review, see Linden et al., 2008). Other works also suggested that $\operatorname{PrP}^{\mathrm{c}}$ could be involved in the neuronal differentiation of $\mathrm{PC} 12$ cells triggered by either interleukin- 6 or nerve growth factor, as shown by increased expression of $\operatorname{PrP}^{\mathrm{c}}$ mRNA levels (Lazarini et al., 1994). Consistent with a pivotal link between $\mathrm{NGF}$ and $\operatorname{PrP}^{\mathrm{c}}, \operatorname{PrP}^{\mathrm{c}}$ mRNA expression was also increased after intracerebral injection of this growth factor in cholinergic neurons (Mobley et al., 1988). Accordingly, Satoh et al. (1998) reported on cell-specific modulation of $\mathrm{PrP}^{\mathrm{c}}$ mRNA levels after treatment with other cytokines (interleukin $1 \beta)$, growth factors (tumor necrosis $\alpha$ ), and tumor promoting drugs (phorbol esters).

Molecular cloning of the human PRNP gene promoter facilitated the understanding of the transcriptional regulation of $\operatorname{PrP}^{c}$ (Funke-Kaiser et al., 2001; Mahal et al., 2001). Thus, the $5^{\prime}$-flanking region of PRNP revealed several putative binding sites for transcription factors including Sp1, AP1, AP2, c-REL, and Nkx2-5, suggesting stimulus-dependent and cellspecific mechanisms of transcriptional regulation. Interestingly, Mahal et al. (2001) also reported a CATG sequence located $746 \mathrm{nt}$ upstream to the transcriptional start site of the human PRNP gene. This CATG motif partially mimics the p53 consensus binding site sequence (el-Deiry et al., 1992). Whether this putative p53-binding domain was functional remained to be established. Nevertheless, the concomitant presence of p53 and SP-1 binding sequences on the PRNP promoter was interesting with respect to the fact that these two transcriptional factors were reported to physically interact to form functional hetero-complexes (Borellini and Glazer, 1993; MacLeod, 1993; Gualberto and Baldwin, 1995).

Our study clearly demonstrates that p53 acts as a functional activator of the PRNP gene promoter transcription. First, p53 deficiency drastically lowers $\operatorname{PrP}^{\mathrm{c}}$ expression, mRNA levels, and promoter transactivation that all could be rescued by transient transfection of p53 cDNA. Second, substitution of the putative p53-binding site CATG by AGCA fully abolishes p53-dependent upregulation of $\mathrm{PrP}^{\mathrm{c}}$ transcription. Third, ChIP unravels a direct interaction between $\mathrm{p} 53$ and $\operatorname{PrP}^{\mathrm{c}}$ promoter. Therefore, our study establishes a physical and functional link between p53 and PRNP promoter triggering transcriptional activation and increased expression of $\operatorname{PrP}^{\mathrm{c}}$. Noteworthy, a very recent study described an ATM (ataxia-telangectasia-mutated)-mediated binding of 553 to the PRNP promoter in response to copperinduced oxidative stress that promotes an elevation of $\mathrm{PrP}^{\mathrm{c}}$ (Qin et al., 2009).

It should be noted, however, that the PRNP gene did not emerge when a global mapping of p53-binding sites in the human 
genome was performed recently by ChIP coupled to paired-end ditag sequencing (PET) (Wei et al., 2006). This likely reflects a weak physical PRNP promoter/p53 interaction as could have been expected from the fact that the human $\mathrm{PrP}^{\mathrm{c}}$ promoter only contains one of the two canonical p53-binding CATG half-sites.

Since we previously established that PSs could modulate p53 expression (Alves da Costa et al., 2006), this prompted us to examine first whether PSs could control $\mathrm{PrP}^{\mathrm{c}}$ expression. A first set of experiments clearly showed that PS depletion lowered $\mathrm{PrP}^{\mathrm{c}}$ levels in cell homogenates as well as in intact cultured cells, and reduced $\mathrm{PrP}^{\mathrm{c}}$ mRNA levels and its promoter transactivation. Interestingly, $\operatorname{PrP}^{\mathrm{c}}$ immunoreactivity, promoter transactivation, and mRNA levels could be restored by PS1 and PS2 expression in PS-deficient fibroblasts. This clearly established that endogenous PSs could modulate $\operatorname{PrP}^{\mathrm{c}}$ transcription. That this phenotype was linked to the reported ability of PSs to display $\gamma$-secretase activity was demonstrated by the fact that the presenilin-binding $\gamma$-secretase inhibitor DAPT indeed reduced $\operatorname{PrP}^{c}$ expression in primary cultured neurons.

PS-dependent $\gamma$-secretase targets a series of substrates (Wakabayashi and De Strooper, 2008) that could have been theoretically considered as putative mediators of p53-dependent PS-associated modulation of $\operatorname{PrP}^{\mathrm{c}}$. We examined the possibility that PS/ $\gamma$-secretase-mediated cleavages of $\beta A P P$ and APLP could be responsible for this phenotype, because we previously established that AICD and ALID ( $\beta$ APP-like intracellular domain), the intracellular metabolites of the $\beta$ APP and APLP, respectively, generated by PS-dependent $\gamma$-secretase activity, could control p53 levels (Alves da Costa et al., 2006). Five lines of data indicate that this was indeed the case: first, $\beta$ APP overexpression increases $\mathrm{PrP}^{\mathrm{c}}$ expression; second, $\beta$ APP and APLP depletion lowered $\operatorname{PrP}^{\mathrm{c}}$ immunoreactivity, promoter transactivation. and mRNA levels in fibroblasts as well as in mice brains; third, $\beta$ APP and APLP cDNA transfection could rescue $\operatorname{PrP}^{\mathrm{c}}$ promoter transactivation and mRNA levels in $\beta \mathrm{APP} /$ APLP2 deficient cells; fourth, AICD increases $\mathrm{PrP}^{\mathrm{c}}$ expression, promoter transactivation, and mRNA levels after overexpression in both $\beta$ APP/APLP2deficient fibroblasts, whereas AICDtransgenic mice display higher $\operatorname{PrP}^{\mathrm{c}}$ levels than wild-type animals; and fifth, AICD-mediated modulation of $\operatorname{PrP}^{\mathrm{c}}$ mRNA levels was fully abolished by p53 deficiency. Overall, our study demonstrates for the first time that PSs control $\mathrm{PrP}^{\mathrm{c}}$ levels via its ability to generate AICD. Thereafter, AICD increases
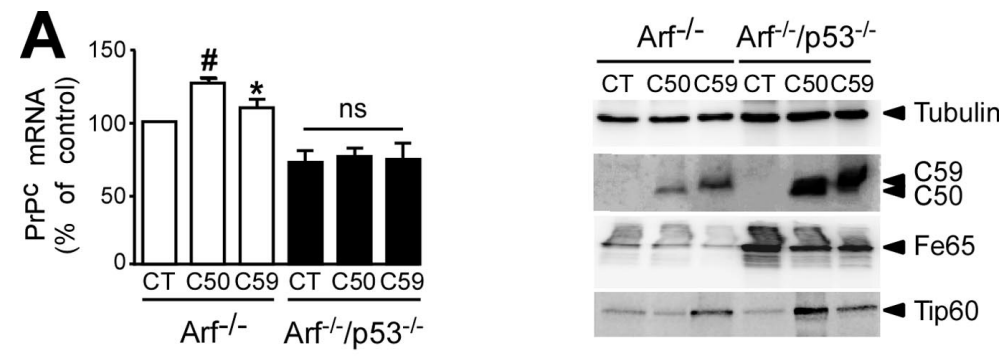
B
p53 consensus binding site: agaCATGcccagaCATGtcc
p53 binding site on PrP promoter. gggCATGcctggtttacgc
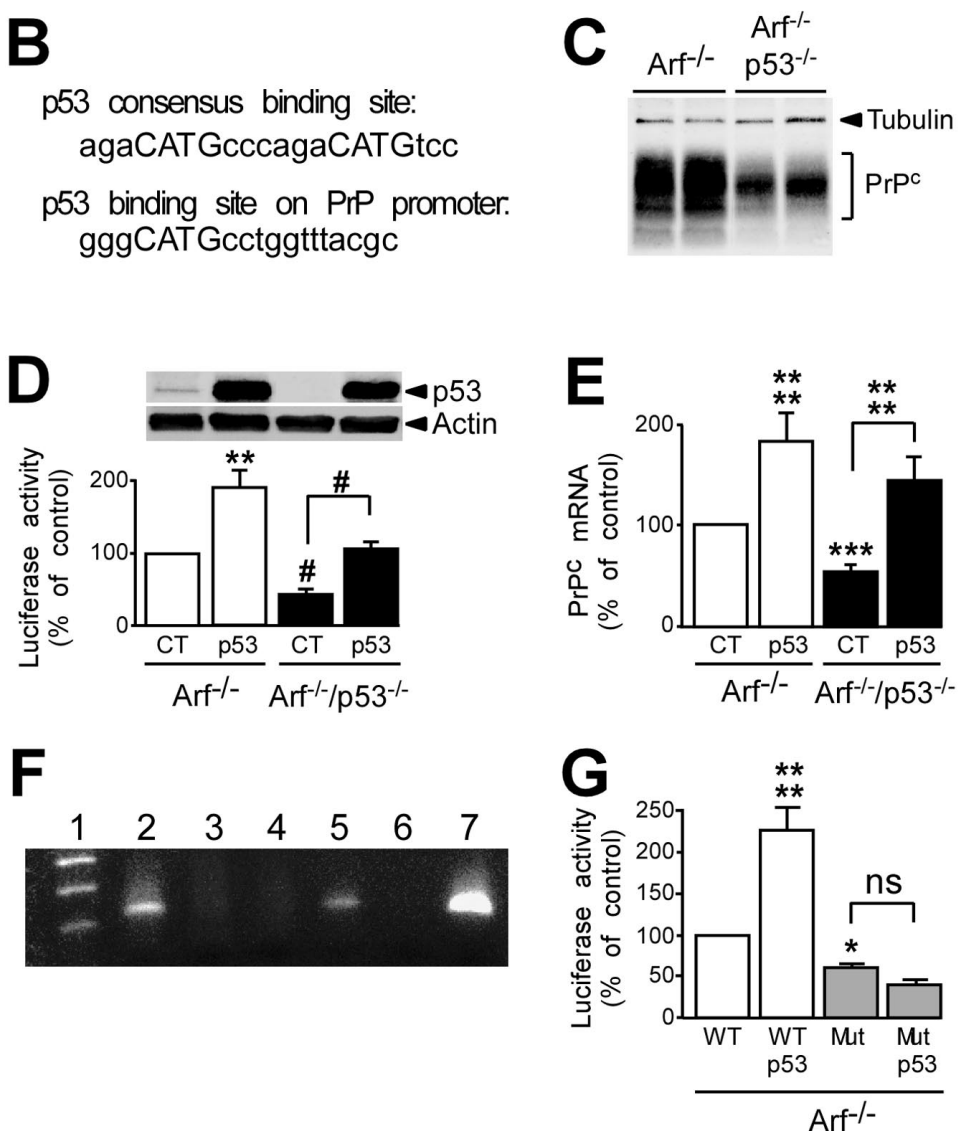

Figure 6. Regulation of PrPC transcription by p53. A, $\mathrm{p} 19^{\mathrm{Arf}-/-}\left(\mathrm{Arf}^{-1-}\right)$ and $\mathrm{p} 19^{\mathrm{Arf}-/-} \mathrm{p} 53^{-1-}\left(\mathrm{Arf}^{-1-} / \mathrm{p} 53^{-1-}\right)$ fibroblasts were transiently transfected with Fe65 and Tip60 CDNA together with either empty pcDNA3 vector (CT), C50 or C59 CDNA. Thirty-six hours after transfection, $\operatorname{PrP}^{\complement}$ mRNA levels were measured by real-time PCR as described in Materials and Methods. Right panel shows representative Western blot analyses of each of the over-expressed proteins. Bars express percentage of control (Arf ${ }^{-1-}$ cells transfected with pcDNA3, Fe65 and Tip60 CDNA) and represent the means \pm SEM of $4-8$ experiments performed in duplicates. ${ }^{*} p<0.05 ;{ }^{*} p<0.0005 ; n$, not statistically significant. $\boldsymbol{B}$, Alignment of typical $p 53$ consensus binding motive (el-Deiry et al., 1992) with the partial p53-binding site identified on human PrP ' promoter (Mahal et al., 2001) where involved nucleotides are highlighted in high caps. C, PrP ' expression was monitored in $\mathrm{Arf}^{-1-}$ and $\mathrm{Arf}^{-1-} / \mathrm{p5} 3^{-/-}$fibroblasts

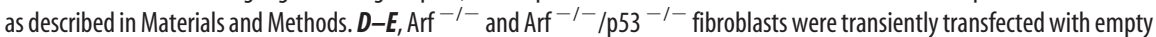
pcDNA3 vector (CT) or p53 CDNA. Thirty-six hours after transfection, PrP ${ }^{C}$ promoter transactivation (D) and RT-PCR analysis of mRNA levels $(\boldsymbol{E})$ were monitored as described in Materials and Methods. Bars express percentage of control pcDNA3-transfected Arf $^{-1-}$ cells and represent the means \pm SEM of 7 and 4 independent determinations, respectively. ${ }^{* *} p<0.01$; ${ }^{* * *} p<0.005$; ${ }^{* * * *} p<0.001 ;{ }^{\#} p<0.0005$. $\boldsymbol{F}$, ChIP analysis of $p 53$ binding on the PrP ${ }^{C}$ promoter sequence was performed as described in Materials and Methods. Lane 1: molecular markers, 2: DNA input, 3: lgG control, 4: RNA pol lgG, 5: anti p53 lgG, 6: water, 7: PrPc promoter reporter construct. $\mathbf{G}$, Arf $^{-1-}$ fibroblasts were transiently transfected with pcDNA3 or p53 CDNA together with wildtype $\operatorname{PrP}^{\complement}$ promoter (WT, white bars) or with $\operatorname{PrP}^{\complement}$ promoter mutated on its partial p53-binding site (Mut, gray bars). Thirty-six hours after transfection, luciferase activity was measured as described in Materials and Methods. Values are expressed as a percentage of control (cells transfected with the wild-type PrP ${ }^{c}$ promoter alone, WT) and are the mean \pm SEM of 6 experiments performed in triplicates. ${ }^{*} p<0.05 ;{ }^{* * * *} p<0.001 ; \mathrm{ns}$, not significant.

p53 that ultimately acts as a transcriptional activator of $P R N P$ gene promoter (Fig. 7). Moreover, it appears that AICDmediated cascade leading to the modulation $\operatorname{PrP}^{c}$ is rather specific since other $\gamma$-secretase-derived fragments such as 


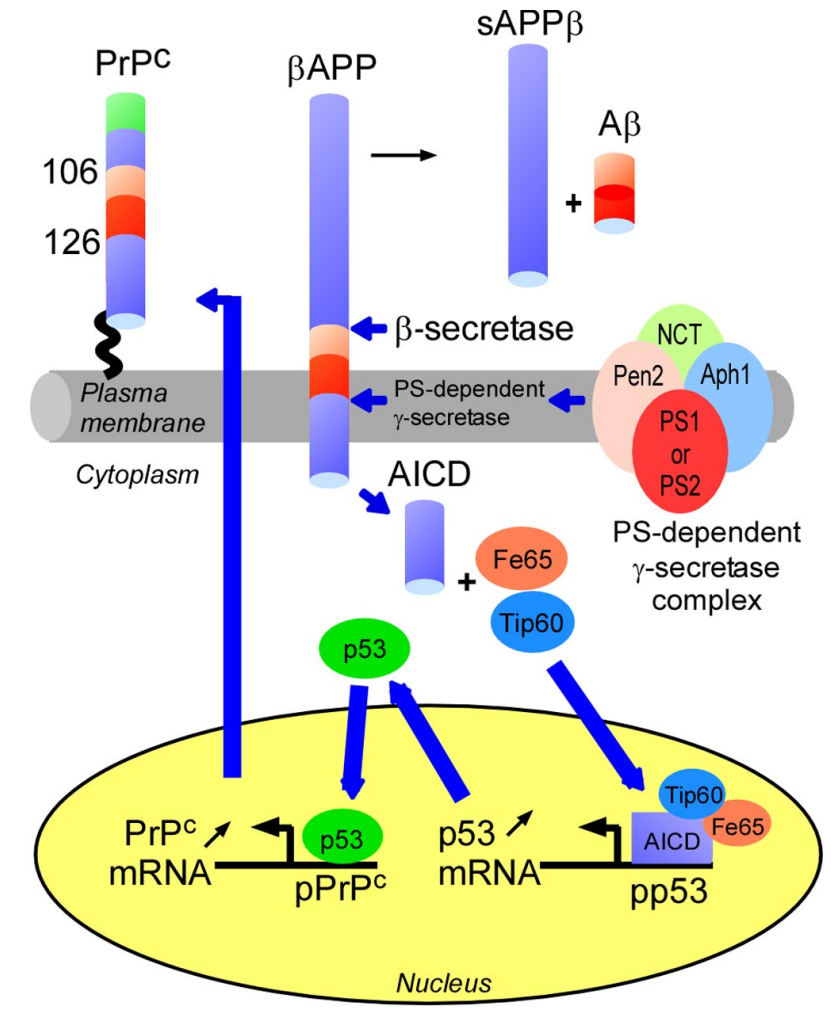

Figure 7. Schematic representation of the $\gamma$-secretase-mediated presenilin-dependent transcriptional activation of PrP ${ }^{c}$ via AICDs and $p 53$. The cleavage of $\beta A P P$ by the $\beta$-secretase BACE1 yields the $(99$ fragment that undergoes subsequent attack by the presenilin-dependent $\gamma$-secretase. This results in the concomitant productions of A $\beta$ and AICD. AICD associates with the adaptor protein Fe 65 and the histone acetyltransferase Tip 60 to form a stable complex that translocates into the nucleus where it can induce the promoter transactivation of several gene targets including $\mathrm{p} 53$ (Alves da Costa et al., 2006) that acts as a direct activator of PrP c promoter transactivation directly (this study). Therefore, PS-dependent $\gamma$-secretase-mediated production of AICD ultimately leads to a p53-dependent augmentation of cellular prion protein expression at the plasma membrane.

NICD or E- and N-cadherin C-terminal fragments did not affect $\operatorname{PrP}^{\mathrm{c}}$ levels.

Interestingly, various neuropathological stigmata have previously been shown to label both Alzheimer's disease (AD)- and prion-affected brains (Powers et al. 1991; Hainfellner et al., 1998), and it has been reported that $\operatorname{PrP}^{\mathrm{c}}$ gene polymorphism could increase the risk factor of developing early onset AD (Dermaut et al., 2003; Riemenschneider et al., 2004). Furthermore, cell biology approaches also indicated that several molecular effectors apparently bridge Alzheimer's disease and prion pathophysiology. Thus, $\operatorname{PrP}^{\mathrm{c}}$ undergoes constitutive and $\mathrm{PKC}$ regulated proteolysis by membrane-bound proteases of the disintegrin family of metalloproteases, namely ADAM10 and ADAM17 (Vincent et al., 2000, 2001). This proteolytic attack that takes place at the 111/112 peptidyl bond, i.e., in the middle of the putative neurotoxic 106-126 region of $\operatorname{PrP}^{\mathrm{c}}$ (Forloni et al., 1993), is reminiscent of the well characterized $\alpha$-secretase cleavage of $\beta A P P$, which occurs inside the $\mathrm{A} \beta$ sequence, is performed by the same enzymes, and is similarly upregulated by protein kinase $\mathrm{C}$ (Checler and Vincent, 2002). $\beta$ APP and $\operatorname{PrP}^{\mathrm{c}}$ not only undergo common metabolic processes but can apparently cross talk. Thus, the levels of $\operatorname{PrP}^{\mathrm{c}}$ and its distribution within cholesterolrich lipid rafts strongly impact on the $\beta$-secretase cleavage of $\beta \mathrm{APP}$ and thereby reduce $\mathrm{A} \beta$ production by restricting the access of BACE1 to $\beta$ APP (Parkin et al., 2007). Together with the present data, these observations establish that the secretases responsible for the metabolism of $\beta \mathrm{APP}$ are also able to interfere with $\mathrm{PrP}^{\mathrm{c}}$ physiology.

Several studies have clearly established that endogenous $\operatorname{PrP}^{c}$ was necessary for the $\mathrm{PrP}$-scrapie-associated ( $\left.\mathrm{PrP}^{\text {s.c. }}\right)$ pathology since mice devoid of $\mathrm{PrP}^{\mathrm{c}}$ resist infection by pathogenic inoculates (Büeler et al., 1993; Brandner et al., 1996). In this context, strategies aimed at reducing endogenous levels of $\operatorname{PrP}^{\mathrm{c}}$ could be seen as theoretical methods to protect against prion infections. This could be envisioned by increasing disintegrin-mediated cleavages as we have proposed (Checler and Vincent, 2002). Is $\gamma$-secretase inhibition another putative therapeutic approach to interfere with prion propagation? This possibility has been supported by a recent very interesting study showing that an orally administered $\gamma$-secretase inhibitor, combined to quinacrine, was able to reduce $\mathrm{PrP}^{\text {s.c. }}$ in the neocortex and hippocampus of mouse brains (Spilman et al., 2008). The present demonstration of a PS-dependent and $\gamma$-secretase-mediated control of $\mathrm{PrP}^{\mathrm{c}}$ transcription provides the molecular basis of the above empirical observation and suggests that $\gamma$-secretase inhibitors could slow down the spread of pathogenic $\mathrm{PrP}^{\text {s.c. }}$ in prion-infected animals simply by reducing its endogenous $\operatorname{PrP}^{c}$ template. Therefore, our work not only describes the tumor suppressor p53 as a transcriptional activator of PRNP gene promoter transcription but also unravels a new PS-dependent function in the control of $\operatorname{PrP}^{\mathrm{c}}$ and potentially opens new perspectives concerning the treatment of prion-associated pathologies.

\section{References}

Aguzzi A, Polymenidou M (2004) Mammalian prion biology: one century of evolving concepts. Cell 116:313-327.

Alves da Costa C, Sunyach C, Pardossi-Piquard R, Sévalle J, Vincent B, Boyer N, Kawarai T, Girardot N, St George-Hyslop P, Checler F (2006) Presenilin-dependent $\gamma$-secretase-mediated control of p53-associated cell death in Alzheimer's disease. J Neurosci 26:6377-6385.

Bellingham SA, Coleman LA, Masters CL, Camakaris J, Hill AF (2009) Regulation of prion gene expression by transcription factors SP1 and MTF-1. J Biol Chem 284:1291-1301.

Borellini F, Glazer RI (1993) Induction of Sp1-p53 DNA-binding heterocomplexes during granulocyte/macrophage colony-stimulating factordependent proliferation in human erythroleukemiacell line TF-1. J Biol Chem 268:7923-7928.

Brandner S, Isenmann S, Raeber A, Fischer M, Sailer A, Kobayashi Y, Marino S, Weissmann C, Aguzzi A (1996) Normal host prion protein necessary for scrapie-induced neurotoxicity. Nature 379:339-343.

Büeler H, Fischer M, Lang Y, Bluethmann H, Lipp HP, DeArmond SJ, Prusiner SB, Aguet M, Weissmann C (1992) Normal development and behaviour of mice lacking the neuronal cell-surface PrP protein. Nature 356:577-582.

Büeler H, Aguzzi A, Sailer A, Greiner RA, Autenried P, Aguet M, Weissmann C (1993) Mice devoid of PrP are resistant to scrapie. Cell 73:1339-1347.

Cao X, Südhof TC (2001) A transcriptively active complex of APP with Fe65 and histone acetyltransferase Tip60. Science 293:115-120.

Cashman NR, Loertscher R, Nalbantoglu J, Shaw I, Kascsak RJ, Bolton DC, Bendheim PE (1990) Cellular isoform of the scrapie agent protein participates in lymphocyte activation. Cell 61:185-192.

Checler F (1999) Presenilins: multifunctional proteins involved in Alzheimer's disease pathology. IUBMB Life 48:33-39.

Checler F, Vincent B (2002) Alzheimer's and prion diseases: distinct pathologies, common proteolytic denominators. Trends Neurosci 25:616-620.

Chen SG, Teplow DB, Parchi P, Teller JK, Gambetti P, Autilio-Gambetti L (1995) Truncated forms of the human prion protein in normal brain and in prion diseases. J Biol Chem 270:19173-19180.

Dermaut B, Croes EA, Rademakers R, Van den Broeck M, Cruts M, Hofman A, van Duijn CM, Van Broeckhoven C (2003) PRNP Val129 homozygosity increases risk for early-onset Alzheimer's disease. Ann Neurol 53:409-412.

De Strooper B, Saftig P, Craessaerts K, Vanderstichele H, Guhde G, Von 
Figura K, Van Leuven F (1998) Deficiency of presenilin 1 inhibits the normal cleavage of amyloid precursor protein. Nature 391:387-390.

Dovey HF, John V, Anderson JP, Chen LZ, de Saint Andrieu P, Fang LY, Freedman SB, Folmer B, Goldbach E, Holsztynska EJ, Hu KL, JohnsonWood KL, Kennedy SL, Kholodenko D, Knops JE, Latimer LH, Lee M, Liao Z, Lieberburg IM, Motter RN, et al. (2001) Functional $\gamma$-secretase inhibitors reduce $\beta$-amyloid peptide levels in brain. J Neurochem 76:173-181.

el-Deiry WS, Kern SE, Pietenpol JA, Kinzler KW, Vogelstein B (1992) Definition of a consensus binding site for p53. Nat Genet 1:45-49.

Forloni G, Angeretti N, Chiesa R, Monzani E, Salmona M, Bugiani O, Tagliavini F (1993) Neurotoxicity of a prion protein fragment. Nature 362:543-546.

Funke-Kaiser H, Theis S, Behrouzi T, Thomas A, Scheuch K, Zollmann FS, Paterka M, Paul M, Orzechowski HD (2001) Functional characterization of the human prion protein promoter in neuronal and endothelial cells. J Mol Med 79:529-535.

Gauczynski S, Peyrin JM, Haïk S, Leucht C, Hundt C, Rieger R, Krasemann S, Deslys JP, Dormont D, Lasmézas CI, Weiss S (2001) The 37-kDa/67$\mathrm{kDa}$ laminin receptor acts as the cell-surface receptor for the cellular prion protein. EMBO J 20:5863-5875.

Gualberto A, Baldwin AS Jr (1995) P53 and Sp1 interact and cooperate in the tumor necrosis factor-induced transcriptional activation of the HIV-1. J Biol Chem 270:19680-19683.

Hainfellner JA, Wanschitz J, Jellinger K, Liberski PP, Gullotta F, Budka H (1998) Coexistence of Alzheimer-type neuropathology in CreutzfeldtJakob disease. Acta Neuropathol 96:116-122.

Heber S, Herms J, Gajic V, Hainfellner J, Aguzzi A, Rülicke T, von Kretzschmar H, von Koch C, Sisodia S, Tremml P, Lipp HP, Wolfer DP, Müller U (2000) Mice with combined gene knock-outs reveal essential and partially redundant functions of amyloid precursor protein family members. J Neurosci 20:7951-7963.

Herreman A, Serneels L, Annaert W, Collen D, Schoonjans L, De Strooper B (2000) Total inactivation of $\gamma$-secretase activity in presenilin-deficient embryonic stem cells. Nat Cell Biol 2:461-462.

Kamijo T, Zindy F, Roussel MF, Quelle DE, Downing JR, Ashmun RA, Grosveld G, Sherr CJ (1997) Tumor suppression at the mouse INK4a locus mediated by the alternative reading frame product $\mathrm{p} 19^{\mathrm{ARF}}$. Cell 91:649-659.

Kanaani J, Prusiner SB, Diacovo J, Baekkeskov S, Legname G (2005) Recombinant prion protein induces rapid polarization and development of synapses in embryonic rat hippocampal neurons in vitro. J Neurochem 95:1373-1386.

Lazarini F, Castelnau P, Chermann JF, Deslys JP, Dormont D (1994) Modulation of prion protein expression by growth factors in cultured mouse astrocytes and PC-12 cells. Mol Brain Res 22:268-274.

Linden R, Martins VR, Prado MA, Cammarota M, Izquierdo I, Brentani RR (2008) Physiology of the prion protein. Physiol Rev 88:673-728.

MacLeod MC (1993) Identification of a DNA structural motif that includes the binding sites for Sp1, p53 and GA-binding protein. Nucleic Acids Res 21:1439-1447.

Mahal SP, Asante EA, Antoniou M, Collinge J (2001) Isolation and functional characterization of the promoter region of the human prion protein gene. Gene 268:105-114.

Mangé A, Milhavet O, Umlauf D, Harris D, Lehmann S (2002) PrPdependent cell adhesion in N2a neuroblastoma cells. FEBS Lett 514:159-162.

Marambaud P, Chevallier N, Barelli H, Wilk S, Checler F (1997) Proteasome contributes to the $\alpha$-secretase pathway of amyloid precursor protein in human cells. J Neurochem 68:698-703.

Mobley WC, Neve RL, Prusiner SB, McKinley MP (1988) Nerve growth factor increases mRNA levels for the prion protein and the $\beta$-amyloid protein precursor in developing hamster brain. Proc Natl Acad Sci U S A 85:9811-9815.

Mouillet-Richard S, Ermonval M, Chebassier C, Laplanche JL, Lehmann S, Launay JM, Kellermann O (2000) Signal transduction through prion protein. Science 289:1925-1928.
Müller T, Meyer HE, Egensperger R, Marcus K (2008) The amyloid precursor protein intracellular domain (AICD) as modulator of gene expression, apoptosis, and cytoskeletal dynamics - relevance for Alzheimer's disease. Prog Neurobiol 85:393-406.

Pardossi-Piquard R, Petit A, Kawarai T, Sunyach C, Alves da Costa C, Vincent B, Ring S, D'Adamio L, Shen J, Müller U, St Georges-Hyslop P, Checler F (2005) Presenilin-dependent transcriptional control of the $A \beta$ degrading enzyme neprilysin by intracellular domains of $\beta$ APP and APLP. Neuron 46:541-554.

Parkin ET, Watt NT, Hussain I, Eckman EA, Eckman CB, Manson JC, Baybutt HN, Turner AJ, Hooper NM (2007) Cellular prion protein regulates $\beta$-secretase cleavage of the Alzheimer's amyloid precursor protein. Proc Natl Acad Sci U S A 104:11062-11067.

Powers JM, Liu Y, Hair LS, Kascsack RJ, Lewis LD, Levy LA (1991) Concomitant Creutzfeldt-Jakob and Alzheimer's disease. Acta Neuropathol 83:95-98.

Prusiner SB (1998) Prions. Proc Natl Acad Sci U S A 95:13363-13383.

Qin K, Zhao L, Ash RD, McDonough WF, Zhao RY (2009) ATMmediatedtranscriptional elevation of prion in response to copperinduced oxidative stress. J Biol Chem 284:4582-4593.

Rieger R, Edenhofer F, Lasmézas CI, Weiss S (1997) The human 37-kDa laminin receptor precursor interacts with the prion protein in eucaryotic cells. Nat Med 3:1383-1388.

Riemenschneider M, Klopp N, Xiang W, Wagenpfeil S, Vollmert C, Müller U, Förstl H, Illig T, Kretzschmar H, Kurz A (2004) Prion protein codon 129 polymorphism and risk of Alzheimer disease. Neurology 63:364-366.

Ryan KA, Pimplikar SW (2005) Activation of GSK-3 and phosphorylation of CRMP2 in transgenic mice expressing APP intracellular domain. J Cell Biol 171:327-335.

Santuccione A, Sytnyk V, Leshchyns'ka I, Schachner M (2005) Prion protein recruits its neuronal receptor NCAM to lipid rafts to activate P59fyn and to enhance neurite outgrowth. J Cell Biol 169:341-354.

Satoh J, Kurohara K, Yukitake M, Kuroda Y (1998) Constitutive and cytokine-inducible expression of prion protein gene in human neuronal cell lines. J Neuropathol Exp Neurol 57:131-139.

Scheinfeld MH, Ghersi E, Laky K, Fowlkes BJ, D’Adamio L (2002) Processing of $\beta$-amyloid precursor-like protein- 1 and -2 by $\gamma$-secretase regulates transcription. J Biol Chem 277:44195-44201.

Spilman P, Lessard P, Sattavat M, Bush C, Tousseyn T, Huang EJ, Giles K, Golde T, Das P, Fauq A, Prusiner SB, Dearmond SJ (2008) A $\gamma$-secretase inhibitor and quinacrine reduce prions and prevent dendritic degeneration in murine brains. Proc Natl Acad Sci U S A 105:10595-10600.

Sunyach C, Cissé MA, da Costa CA, Vincent B, Checler F (2007) The C-terminal products of cellular prion protein processing, $\mathrm{C} 1$ and $\mathrm{C} 2$, exert distinct influence on p53-dependent staurosporine-induced caspase-3 activation. J Biol Chem 282:1956-1963.

Vincent B, Beaudet A, Dauch P, Vincent JP, Checler F (1996) Distinct properties of neuronal and astrocytic endopeptidase 3.4.24.16: a study on differenciation, subcellular distribution and secretion processes. J Neurosci 16:5049-5059.

Vincent B, Paitel E, Frobert Y, Lehmann S, Grassi J, Checler F (2000) Phorbol ester-regulated cleavage of normal prion protein in HEK293 human cells and murine neurons. J Biol Chem 275:35612-35616.

Vincent B, Paitel E, Saftig P, Frobert Y, Hartmann D, De Strooper B, Grassi J, Lopez-Perez E, Checler F (2001) The disintegrins ADAM10 and TACE contribute to the constitutive and phorbol-esters-regulated normal cleavage of the cellular prion protein. J Biol Chem 276:37743-37746.

Wakabayashi T, De Strooper B (2008) Presenilins: members of the gammasecretase quartets, but part-time soloists too. Physiology 23:194-204.

Wei CL, Wu Q, Vega VB, Chiu KP, Ng P, Zhang T, Shahab A, Yong HC, Fu Y, Weng Z, Liu J, Zhao XD, Chew JL, Lee YL, Kuznetsov VA, Sung WK, Miller LD, Lim B, Liu ET, Yu Q, Ng HH, Ruan Y (2006) A global map of p53 transcription-factor binding sites in the human genome. Cell 124:207-219.

Wolfe MS, Xia W, Ostaszewski BL, Diehl TA, Kimberly WT, Selkoe DJ (1999) Two transmembrane aspartates in presenilin-1 required for presenilin endoproteolysis and $\gamma$-secretase activity. Nature 398:513-517. 